
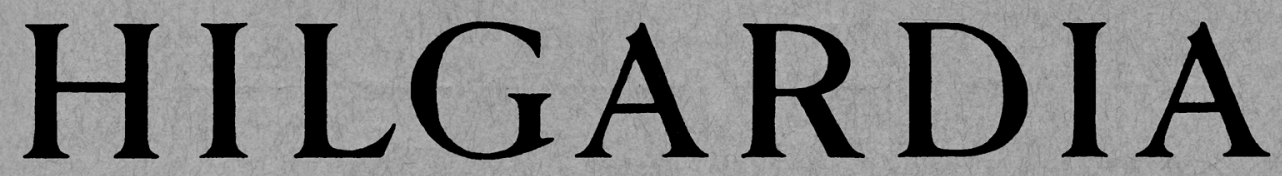

A Journal of Agricultural Science Published by the California Agricultural Experiment Station

\title{
CONTENTS
}

\section{CALIFORNIA ASTER YELLOWS ON VEGETABLE AND SEED CROPS} HENRY H. P. SEVERIN and NORMAN W. FRAZIER

\section{ADDITIONAL ORNAMENTAL FLOWERING PLANTS NATURALLY INFECTED WITH CALIFORNIA ASTER YELLOWS} HENRY H. P. SEVERIN and JULIUS H. FREITAG

\section{WEED-HOST RANGE OF CALIFORNIA ASTER YELLOWS}

NORMAN W. FRAZIER and HENRY H. P. SEVERIN

This Issue Completes Volume 16

UNIVERSITY OF CALIFORNIA · BERKELEY, CALIFORNIA 


\title{
H I \\ A Journal of Agricultural Science Published by \\ the California Agricultural Experiment Station \\ VoL. 16 \\ JUNE, 1945 \\ No. 12 \\ CALIFORNIA ASTER YELLOWS ON VEGETABLE AND SEED CROPS ${ }^{1}$
}

\author{
HENKY H. P. SEVERIN ${ }^{2}$ AND NORMAN W. FRAZIER
}

\section{INTRODUCTION}

The investigations of host plants of aster yellows are covered by three reports. The present paper is confined to the work with aster yellows on vegetable and seed crops. One other paper in this issue describes the disease on ornamental flowering plants (Severin and Freitag, 1945). Weeds experimentally and naturally infected are discussed in a third paper (Frazier and Severin, 1945).

In $1902^{4}$ Smith described aster yellows, especially as it affects the flower; he was the first to notice it in California. The disease is now generally distributed in most counties of the state. Among economic plants, celery is seriously affected (Severin, 1929a) in certain years. During 1931 a general outbreak occurred in the Sacramento Valley, and celery in many fields was plowed under. Lettuce, carrots, parsley, parsnip, and potato (Severin, 1929a, 1932,1940 ) have been demonstrated to be naturally infected; but the disease is of no economic importance at present.

Field investigations of other host plants of this virus were conducted from 1925 to 1943 . Several new vegetable host plants were noted, as recorded in this paper. The infection of seed crops received special attention, and surveys were made of seed farms and the ranches of seed companies. Attempts were made to recover the virus from naturally infected host plants. The symptoms were studied.

\section{METHODS}

The method of recovering the virus from naturally infected host plants and the production of noninfective leafhoppers were the same as in previous investigations (Severin $1929 a, 1942$ ). A detailed account of methods is given in the third paper of this series (Frazier and Severin, 1945).

\footnotetext{
${ }^{1}$ Received for publication April 28, 1944.

2 Entomologist in the Experiment Station.

Junior Entomologist in the Experiment Station.

"See "Literature Cited" at the end of this paper for complete data on citations, referred to in the text by author and date of publication.
} 


\section{HOST RANGE OF VIRUS}

The host range of the aster-yellows virus among economic plants naturally infected includes 11 vegetables, 12 seed crops belonging to 14 species in 12 genera in 6 families, including those previously reported (Severin, 1929a, $1932,1940)$. The season's duration of each plant is given in the following list:

Chenopodiaceae:

Spinacia oleracea $\mathrm{L} ._{\text {. }}{ }^{{ }_{5}}$ spinach, unknown variety; seed crop; annual

Compositae:

Cichorium Intybus L., chicory; seed crop; perennial

Cichorium Endivia L., endive; vegetable; annual or biennial

Scorzonera hispanica L., black salsify; vegetable; perennial

Lactuca sativa L.* lettuce; vegetable (Severin, 1929a) and seed crop; annual

Lactuca sativa L. var. longifolia Lam., Romaine lettuce; vegetable; annual

Cruciferae:

Brassica oleracea L. var. capitata L., cabbage; vegetable and seed crop; biennial

Brassica oleracea L. var. botrytis L., cauliflower; seed crop; biennial

Brassica oleracea L. var. italica Plenck., sprouting broccoli ; seed crop; biennial

Raphanus sativus L., Long White Chinese radish; vegetable and seed crop; annual or biennial

\section{Liliaceae:}

Allium Cepa L., onion; vegetable and seed crop; biennial

Solanaceae:

Solanum tuberosum L., potato (Severin, 1940); herb

\section{Umbelliferae:}

Daucus Carota L. var. sativa DC., Short White and Yellow Belgian carrots; vegetable (Severin, 1932) and seed crop; annual or biennial

Petroselinum crispum Nym., Double Curled parsley and unknown variety; seed crop; biennial or perennial

Petroselinum hortense Hoffm. var. radicosum Bailey, Hamburg or turnip-rooted parsley; vegetable (Severin, 1932); biennial

Apium graveolens L. var. dulce DC., Golden Self-Blanching celery; vegetable (Severin, $1929 a$ ) and seed crop; Utah celery, vegetable; biennial or perennial

Apium graveolens var. rapaceum, celeriac; vegetable; biennial

Pastinaca sativa L., ${ }^{*}$ Hollow Crown parsnip; vegetable (Severin, 1932) and seed crop; biennial

The virus overwinters in biennials and perennials; it also is carried over by overwintering leafhoppers.

The virus was recovered by previously noninfective short-winged and longwinged aster leafhoppers from the naturally infected host plants and transferred to healthy aster or celery.

\section{IIIIACEAE, LIIY FAMILY}

Onion (Allium Cepa) plants grown from bulbs were collected on September 22, 1941, in a canyon of the Montara Mountains. These specimens showed chlorosis of the leaves, which on some plants drooped and on others were twisted and intertwined. Onions grown for seed production near Cotati were

\footnotetext{
B The asterisk indicates overlapping host ranges of California and New York aster-yellows viruses.
} 
also shown to be naturally infected with aster yellows during the summer of 1943. Since the symptoms were not those of yellow dwarf (Drake, Tate, and Harris, 1932, 1933), tests were made to recover the California aster-yellows virus from the diseased onions. Attempts were made to infect healthy onion plants experimentally by means of different species of leafhoppers.

The virus was recovered from naturally infected onion by previously noninfective short-winged aster leafhopper, Macrosteles divisus (Uhl.), and by the long-winged race of the same species. The former transmitted it to healthy celery. The long-winged aster leafhopper on celery usually dies before the so-called virus incubation period is completed in the insect; hence it was transferred to healthy asters and transmitted the virus to them.

TABLE 1

Longevity of Five Leafhopper Vectors on Onion Plants

\begin{tabular}{|c|c|c|c|c|c|}
\hline \multirow{2}{*}{ Common and scientific names of leafhoppers } & \multirow{2}{*}{$\begin{array}{c}\text { Lots } \\
\text { of } 20 \\
\text { adults } \\
\text { used }\end{array}$} & \multicolumn{2}{|c|}{ Longevity of males } & \multicolumn{2}{|c|}{ Longevity of females } \\
\hline & & Range & Average & Range & Average \\
\hline 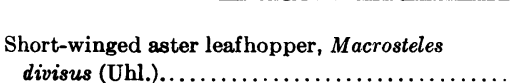 & $\begin{array}{c}\text { number } \\
24\end{array}$ & $\begin{array}{l}\text { days } \\
3-10\end{array}$ & $\begin{array}{r}\text { days } \\
6.7\end{array}$ & $\begin{array}{l}\text { days } \\
13-21\end{array}$ & $\begin{array}{l}\text { days } \\
18.4\end{array}$ \\
\hline $\begin{array}{c}\text { Long-winged aster leafhopper, Macrosteles } \\
\text { divisus (Uhl.) } \ldots \ldots \ldots \ldots \ldots \ldots \ldots \ldots \ldots \ldots\end{array}$ & 17 & $4-8$ & 5.6 & 8-22 & 136 \\
\hline $\begin{array}{l}\text { Mountain leafhopper, Colladonus montanus } \\
\quad \text { (V. D.) } \ldots \ldots \ldots \ldots \ldots \ldots \ldots \ldots \ldots \ldots \ldots \ldots \ldots\end{array}$ & 9 & $3-6$ & 4.5 & $5-10$ & 7.5 \\
\hline $\begin{array}{l}\text { Geminate leafhopper, Idiodonus geminatus } \\
\quad(V . \text { D.) } \ldots \ldots \ldots \ldots \ldots \ldots \ldots \ldots \ldots \ldots \ldots \ldots \ldots \ldots \ldots \ldots \\
\text { Acute-winged leafhopper, Acinopterus angulatus }\end{array}$ & 9 & 4-12 & 7.0 & $4-10$ & 6.2 \\
\hline 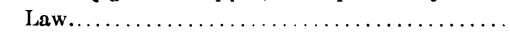 & 4 & $31-33$ & 32.0 & $18-26$ & 22.0 \\
\hline
\end{tabular}

Danvers Yellow Globe, Red Wethersfield, and Sweet Bermuda onion plants grown from sets, and Danvers Yellow Globe grown from seeds were all experimentally infected. These onion plants were exposed to lots of either 20 infective short-winged or 20 long-winged aster leafhoppers until the insects died on the plants. After symptoms appeared on the infected onion plants, the virus was recovered by lots of 20 previously noninfective short-winged or long-winged aster leafhoppers and transferred to healthy celery and asters respectively.

The long-winged aster leafhopper, which was the most efficient vector of the virus to onion, was abundant in the canyons of the Montara Mountains. Short-winged aster leafhoppers were captured on weeds growing in onion fields and along roadsides near Cotati.

The virus was also transmitted to onion plants by the mountain leafhopper, Colladonus montanus (V. D.) $=$ (Thamnotettix montanus V. D.); the geminate leafhopper, Idiodonus geminatus (V. D.) $=$ (Thamnotettix geminatus V. D.) ; and the acute-winged leafhopper, Acinopterus angulatus Law.

Table 1 shows the longevity of the last living male and female in lots of 20 adults of the 5 vectors on onions. The 5 vectors failed to complete the nymphal stages on onions.

The first symptom on experimentally infected onion plants grown from seeds or sets is a yellowing of the basal portion of the youngest leaves, gradually spreading until these entire leaves are affected. Sometimes the chlorotic 
leaves twist and intertwine as described on celery, carrot, Hamburg or turniprooted parsley, and parsnip (Severin 1929a, 1932). Sometimes, in the later stages of the disease, the leaves droop and wilt, and the plants die.

The symptoms on naturally infected onions grown for seed vary in different plants. Onion plants infected before the peduncle developed often showed twisted and intertwined leaves, yellow or orange in color. Frequently the pedicels, or flower stems, in the terminal umbel were greatly elongated (plate $1, A)$. The most striking symptom was the production of bulbils or bulblets (Bailey, 1924) instead of seeds in the umbel (plate $1, B$ ). The bulblets developed yellow or green leaves (plate $1, C$ ). Often each bulblet was on a pedicel (plate $1, D$ ), or some were sessile and others on pedicels (plate $1, E$ ). Experimentally infected seed crops grown from sets also developed these symptoms. The manifestations of aster yellows on the umbels are called "onion shaggy head" or, according to KenKnight (1943), "frizzle top."

As a result of scheduling the reading of a paper by the senior author, however, requests for information were received from W. J. Virgin ${ }^{6}$ and Glen KenKnight. ${ }^{7}$ In response, California aster yellows on onions was described to them and identified in Virgin's photographs of diseased onions. The evidence for natural and experimental infection of this vegetable was reported to them, and the vectors were given. Though no mention was made of the source, it was presumably on the basis of this correspondence that KenKnight (1943), apparently failing to realize that the information was given confidentially in advance of publication, issued the following statements :

There are two strains of the aster-yellows virus, the Eastern or Typical Strain and the Western or California Strain. These differ in host range. It is possible that both are present in Idaho. Both strains of the virus are spread by the six-spotted leafhopper, and it has been shown that the California Strain can be spread by about twenty species of other leafhoppers.

Onion plants affected with aster yellows ("frizzle top") produce seed stalks which have leafy structures instead of floral parts. A healthy and diseased seed head are shown on the cover of this leaflet.

Bulblets separated from the umbels from infected plants were planted, and some grew. Previously noninfective short-winged and long-winged aster leafhoppers recovered the virus from these onions and transferred it to healthy celery and aster's respectively.

The incubation period of the disease in onion plants grown from sets ranged from 9 to 23 days, an average of 16.3 days; and in Danvers Yellow Globe seedlings from 10 to 20 days, an average of 15.0 days, when the basal portion of the youngest leaves became chlorotic.

Kunkel $(1926,1931)$ reported that he experimentally transmitted the New York aster-yellows virus by means of the aster leafhopper, Macrosteles divisus $=$ (Cicadula sexnotata Uhl.), to 184 species of plants in 151 genera belonging to 38 families. But he does not list a single plant of the family Liliaceae, to which the onion belongs. All our attempts to transmit the eastern

\footnotetext{
- Virgin, W. J. Associate Plant Pathologist in the Idaho Agricultural Experiment Station; letter to senior author dated July 15, 1942.

${ }^{7}$ KenKnight, Glen. Associate Plant Pathologist in the Idaho Agricultural Experiment Station; letter to senior author dated January 15, 1943.
} 
aster-yellows virus ${ }^{8}$ to onions by means of short-winged and long-winged aster leafhoppers were failures.

Doolittle and Wellman (1934) reported that southern celery-mosaic virus, transmitted by the cotton or melon aphid, Aphis gossypii Glover, was the

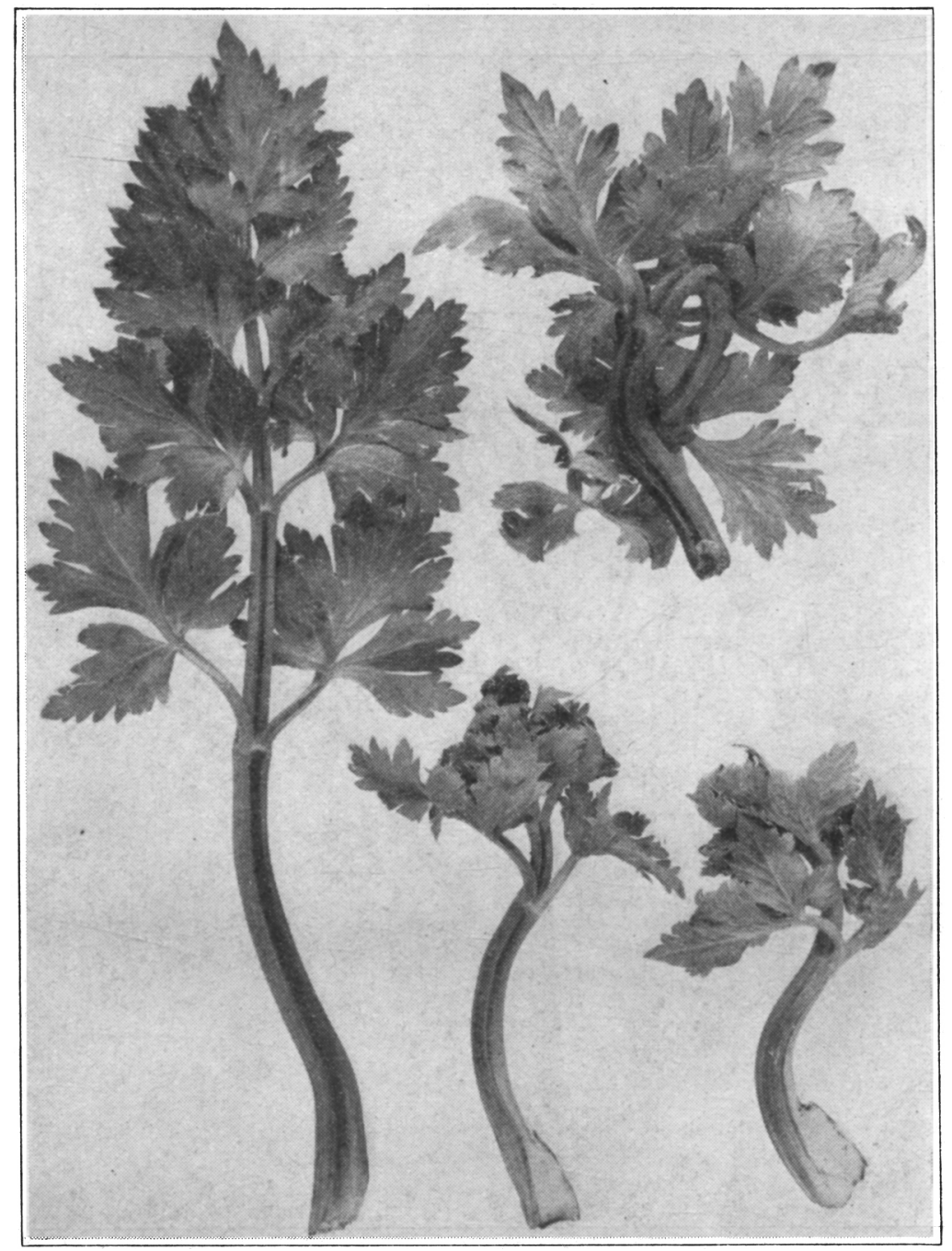

Fig. 1.-Celeriac naturally infected with aster yellows, showing shortened, curved, and twisted petioles of youngest leaves.

first definitely established case of a mosaic virus affecting both dicotyledonous and monocotyledonous plants. The natural infection of onions with California aster yellows is the first example of a leafhopper-transmitted virus of the yellows group affecting both dicotyledonous and monocotyledonous plants.

\footnotetext{
${ }^{8}$ Infected asters were received from L. M. Black, Rockefeller Institute for Medical Research, Princeton, New Jersey.
} 


\section{UMBELLIFERAE, PARSLEY FAMIIY}

Celery (Apium graveolens var. dulce) grown for seed was demonstrated to be naturally infected with aster yellows. Diseased plants were common in the fields between Davis and Sacramento during the outbreak in 1931. The in-

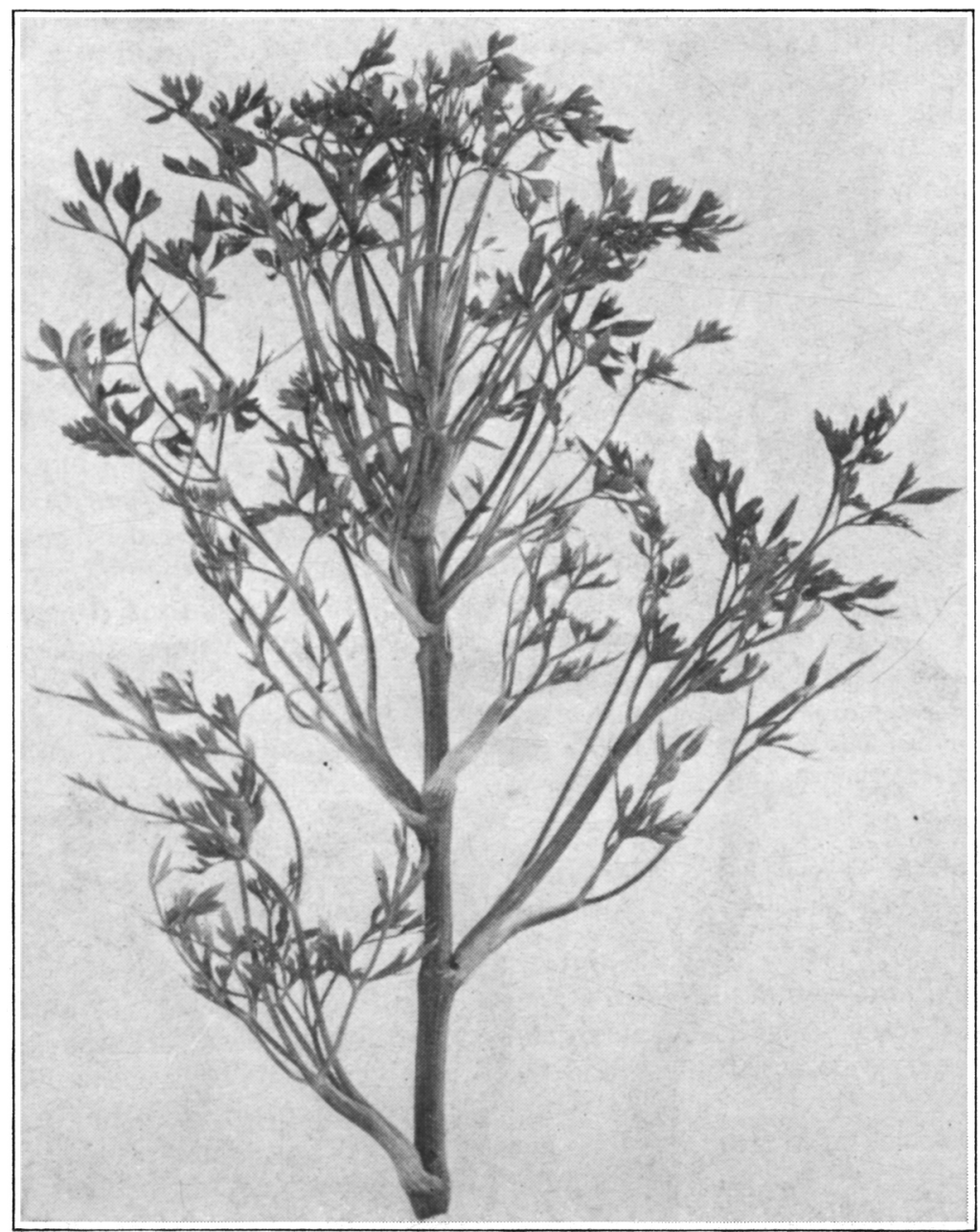

Fig. 2.-Parsley plant, grown for seed, naturally infected with aster yellows, showing numerous axillary shoots at the apical end of the main seedstalk. Umbels failed to develop.

fected plants were stunted and chlorotic, with numerous bunched shoots at the apical ends of the branches (plate 2, $C$ ). Severin (1929a) has described the symptoms on celery in a previous paper.

Celeriac (Apium graveolens var. rapaceum) was proved to be naturally infected with aster yellows. Diseased plants were common in a commercial vegetable field near San Leandro during the autumn of 1936 . The petioles of 
the innermost or youngest leaves are shortened, curved, and twisted (fig. 1); sometimes they intertwine.

Parsley (Petroselinum crispum) grown for seed was shown to be naturally infected with aster yellows. In 1933, 1 per cent of Double Curled parsley plants had been infected with the virus before transplantation in the San

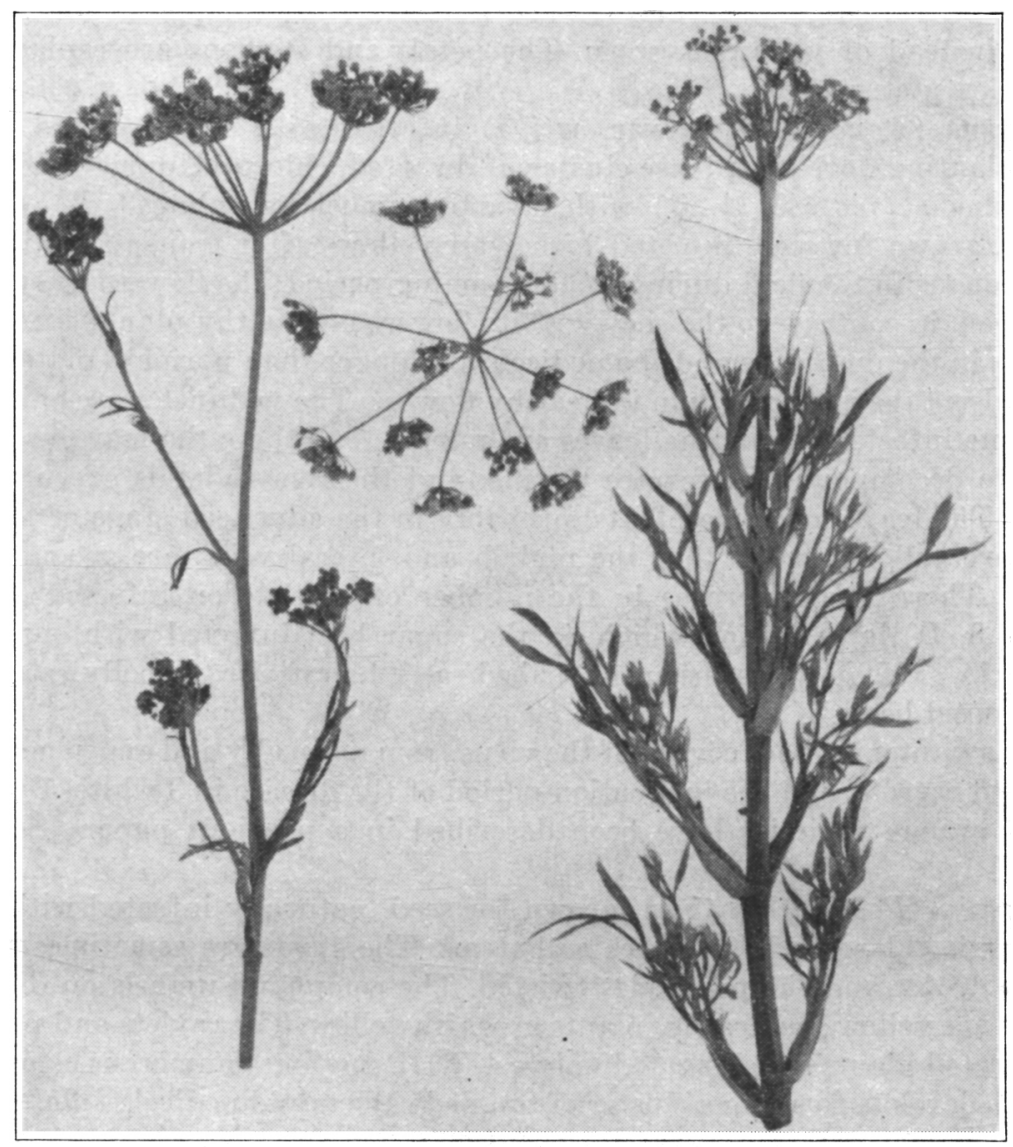

Fig. 3.-Parsley plants, grown for seed, naturally infected with aster yellows, showing dwarfed compound umbels.

Juan Valley. Diseased plants after transplantation in the field are chlorotic and stunted, with a dense growth of adventitious shoots (plate $2, E$ ). The petioles of some of the leaves are twisted (plate 2,D). A previous paper (Severin, 1932) describes the symptoms on three varieties of parsley experimentally infected, together with the incubation period of the disease.

Parsley, grown for seed, with dense clusters of axillary shoots on all stems and with deep green leaves was common on seed farms in the Salinas Valley. The axillary shoots form a compact cluster of leaves at the apical ends of the main and lateral seedstalks (fig. 2). The lateral seedstalks are short and 
bear upright secondary shoots. Umbels fail to develop on such plants (fig. 2). The virus was recovered from plants showing these symptoms and was transferred to healthy asters and celery.

On the same seed farm there were occasional infected parsley plants that did develop umbels. The pinnately compound leaves on these plants are chlorotic and curled outward, and the compound leaves are dwarfed or absent on the lateral seedstalks (fig. 3). The flowers of the compound umbels are green instead of yellowish green. The petals and stamens are replaced by green leafy structures.

Carrots (Daucus Carota var. sativa) infected with aster yellows before transplanting develop a dense cluster of dwarfed, chlorotic, upright adventitious shoots (plate $3, A, B$ ) with dwarfed umbellets (plate $3, B$ ). Carrot plants, grown for seed. infected with aster yellows after transplantation are conspicuous in the field during the blossoming period; the flowers are yellowish green, in contrast to the showy white flowers on healthy plants. The outer raylets in the umbellets and the pedicels are longer than normal (plate $3, C$ ). The calyx tube is longer than in healthy flowers. The peduncles are chlorotic. On some infected plants the leaves are purple; on others the margins of the ninnate decompound leaves are purple, and the remainder is green (plate $8, B)$. The leaves on some plants, probably in the advanced stage of the disease, are yellow, except that the midrib and lateral veins are green (plate $8, A)$. There is an increase in the number of rootlets on infected carrots (nlate $3, D$ ), a condition which, in the sugar beet infected with curly top (Severin, 1929b), has been described as "hairy" or "woolly root" or "whiskered beets."

The svmptoms, the recovery of the virus from naturally and experimentally infected carrots, and the incubation neriod of the disease in 3 white, 1 yellow, and 7 orange varieties have been described in a previous paper (Severin, 1932).

Parsnip (Pastinaca sativa), grown for seed, naturally infected with aster yellows is chlorotic, both leaves and stems. The stems are sometimes curled (plate $4, A$ ), and the peduncles twisted. The compound umbels on diseased plants are yellow; on healthy plants greenish yellow. The raylets and pedicels on infected plants are elongated (plate $4, B$ ). Sometimes numerous compound umbels develop, forming a cluster of tangled raylets and pedicels (plate $4, C$ ).

\section{CRUCIFERAE, MUSTARD FAMILY}

Cabbage (Brassica oleracea var. capitata) near Irvington in 1939 was found to be naturally infected with aster yellows. Such plants are dwarfed and usually form no heads or very small heads. The youngest leaves exhibit a clearing of the veins. As the leaves grow older, the veins swell on both upper and lower surfaces, and become white. The youngest leaves are a normal green, the older leaves chlorotic, and the oldest leaves white. Successive older leaves become more and more outwardly and downwardly curled toward the petioles.

Cauliflower (Brassica oleracea var. botrytis) grown for seed near Irvington and in the Salinas Valley was naturally infected. Often the lateral flower stalks are curved or twisted (plate 5). The flower clusters are usually dwarfed 
on most of the stalks, with short peduncles and pedicels. Toward the apical end of the stems, however, the peduncles and pedicels are often elongated, forming a tangled cluster. No study has been made of the flower abnormalities of cauliflower naturally infected with aster yellows, since the flower buds were not expanded.

Sprouting broccoli (Brassica oleracea var. italica) near Irvington in 1939 showed symptoms of aster yellows. A profuse proliferation of the inflorescence occurs, accompanied by phyllody, the tendency of the floral organs to resemble leafy structures (plate $6, A$ ) ; and by virescence, or greening, of the flowers. The pedicels or stems of the flowers are elongated. The sepals are

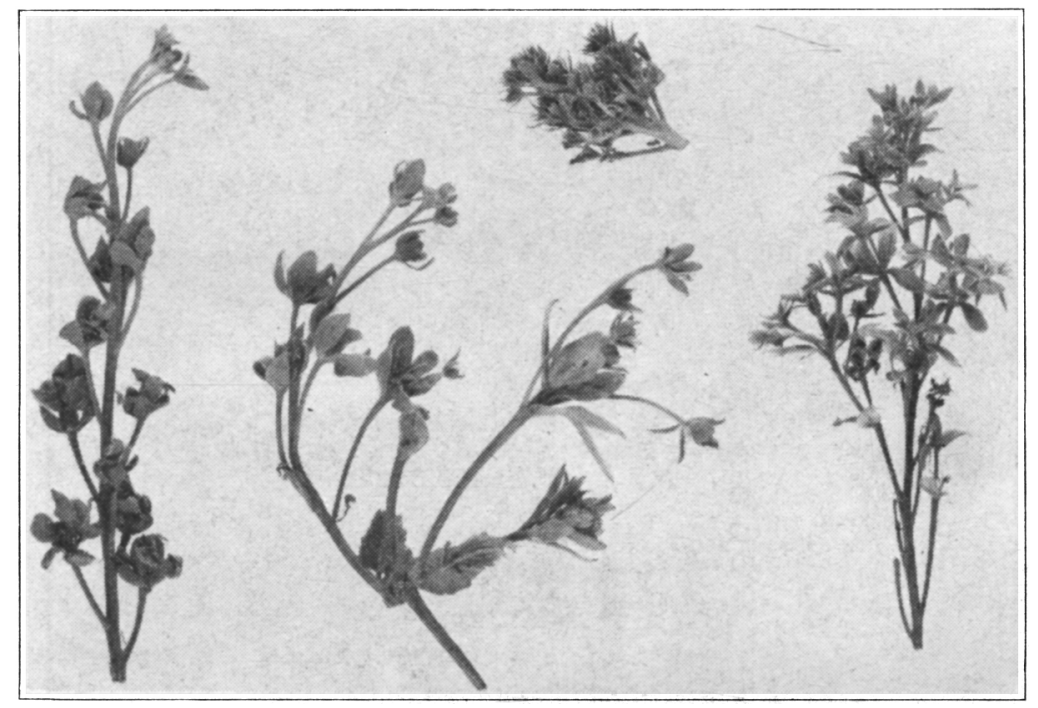

Fig. 4.-Radish plants, grown for seed, naturally infected with aster yellows, showing proliferation of the flowers; the petals, stamens, and gynoecium are replaced by leafy structures.

enlarged, the petals reduced; both are leafy and green. The stamens are usually reduced, but often enlarged and green; when enlarged the pollen sacs expand to form leafy structures; the filaments are elongated into a stem; and thus the stamens are replaced by bipinnate leafy structures (plate $6, B$ ). The gynoecium is elongated, sometimes club-shaped; the carpels bifurcate and leafy (plate $6, B$ ).

Radish (Raphanus sativus), grown for seed, manifesting natural infection with aster yellows was common on seed farms in the Salinas Valley. Tufts of green flowers occur on the apical ends of the seedstalks instead of the showy white flowers seen on healthy plants of the same variety. A proliferation of the flowers occurs, successive flowers with long pedicels developing from the ovaries (fig. 4). Often the petals, stamens, and gynoecium are replaced by leafy structures (fig. 4).

Long White Chinese radish collected near Irvington was demonstrated to be naturally infected with aster yellows. 


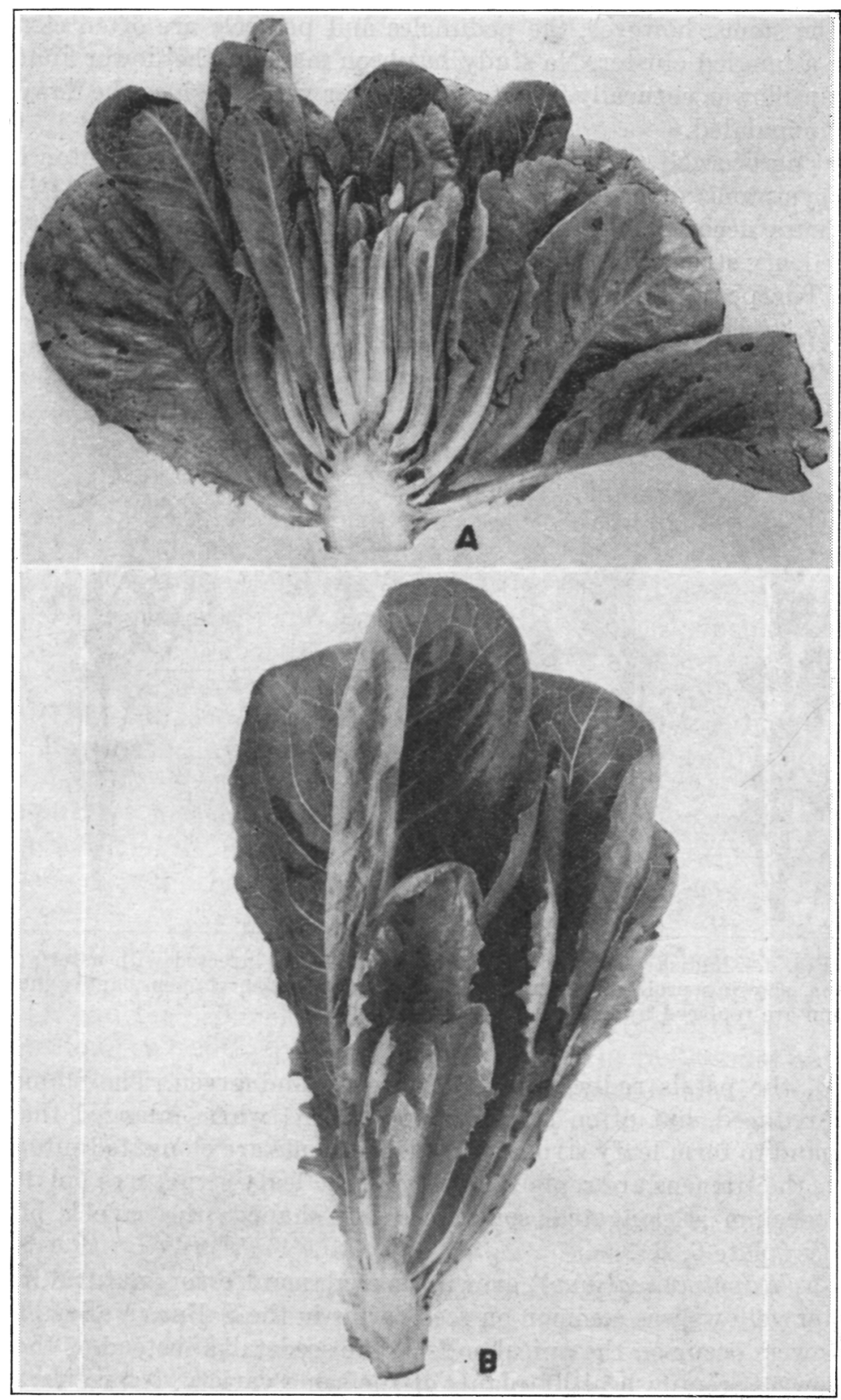

Fig. 5.-Longitudinal sections of Romaine lettuce: $A$, flattened head of diseased plant showing outward-curled, dwarfed, chlorotic youngest leaves; $B$, upright and narrow or columnar head of healthy plant. 


\section{COMPOSITAE, COMPOSITE FAMILY}

Lettuce (Lactuca sativa) grown for seed in the Santa Clara Valley was a failure in 1943, owing to aster yellows and spotted wilt. Infected plants often fail to develop flower stalks. Some plants develop a short flower stalk; on them the lower leaves are normal, whereas the youngest leaves are yellow, dwarfed, and curled outward instead of inward. The stems are dwarfed, and often the veins and veinlets are cleared. The most conspicuous symptom on plants with long flower stalks is the upright or vertical branches, with sec-

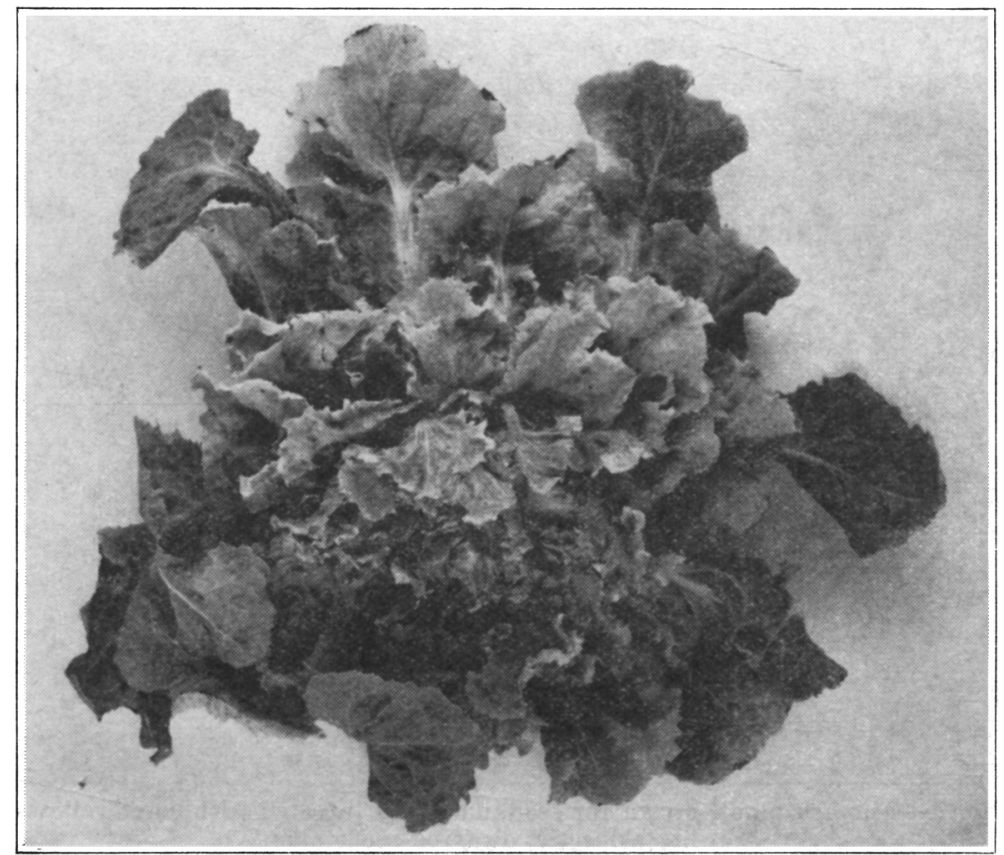

Fig. 6.-Endive naturally infected with aster yellows, showing stunted, flattened, and yellow leaves, with heart leaves curled outward and dwarfed.

ondary shoots arising from the axil of the leaves at the apical end of the erect flower head (plate 7, $A$ ). Sometimes the branches are curved or twisted (plate $7, B)$. A reliable symptom in late-infected plants is the enlarged flower buds (plate $7, C$ ); the rays are green instead of yellow.

Romaine lettuce (Lactuca sativa var. longifolia) in the South San Francisco vegetable gardens was proved to be naturally infected with aster yellows. The head is flattened in infected plants (fig. 5, A), instead of upright and narrow or columnar as in healthy plants (fig. 5, B). A longitudinal section of the head of a diseased plant shows outward-curled, dwarfed, chlorotic leaves (fig. 5, $A$ ).

A single chicory (Cichorium Intybus) plant 6 feet tall, grown for seed on a farm in the Santa Clara Valley, was naturally infected with aster yellows. The most striking symptoms are the numerous axillary shoots on all branches. 
The basal part of these shoots and the midrib of the leaves are white. The margin of some of the leaves is undulating or wavy; sometimes the leaf is twisted into a corkscrew (plate $8, C$ ). The flowers, in heads, are bright azure blue on healthy plants; but on the infected plant the buds are dwarfed, fail to expand, and are surrounded by linear leafy structures (plate $8, C$ ).

Endive (Cichorium Endivia) in the South San Francisco and Colma vegetable districts was naturally infected with aster yellows. ${ }^{9}$ The symptoms on

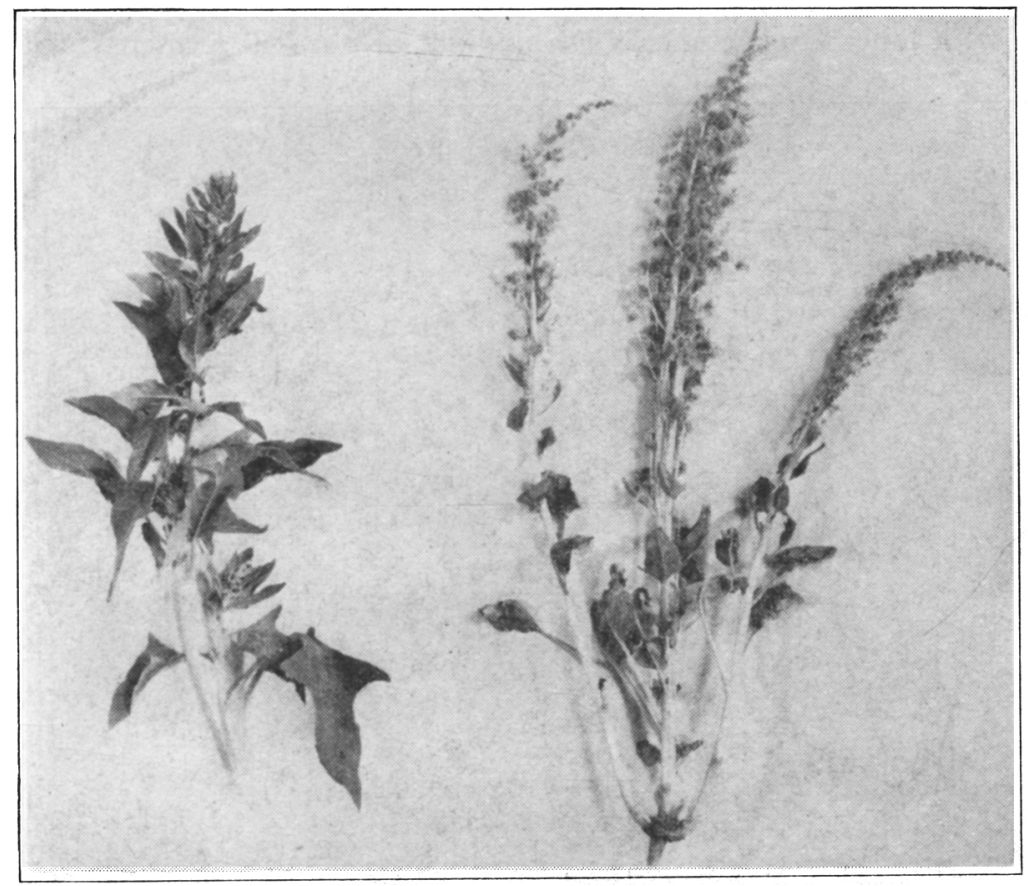

Fig. 7.-Spinach plant, grown for seed, naturally infected with aster yellows, showing chlorotic, dwarfed seedstalks.

endive are somewhat similar to those on lettuce. The most striking symptoms are stunting of the entire plant and yellowing of the leaves (fig. 6).

Black salsify (Scorzonera hispanica) in the Colma vegetable districts was also naturally infected. The long-winged petioles intertwine. The youngest leaves are chlorotic; but the older leaves are green.

\section{CHENOPODIACEAE, GOOSEFOOT OR SALTBUSH FAMILY}

Spinach (Spinacia oleracea) grown for seed was rarely found to be naturally infected with aster yellows. Infected plants are chlorotic and dwarfed, with short seedstalks (fig. 7). The youngest leaves show a clearing of the veins and veinlets.

\footnotetext{
${ }^{9} \mathrm{We}$ are indebted to C. M. Tompkins, who collected endive and black salsify that was naturally infected with the aster-yellows virus.
} 


\section{HOST-RANGE DIFFERENCES OF CALIFORNIA AND NEW YORK ASTER YELLOWS}

Kunkel $(1926,1931)$, in his host-range studies, lists no plant of the family Ijiliaceae. All our attempts to infect onions with the virus of New York aster yellows were unsuccessful.

Kunkel $(1926,1931)$ lists eight vegetables as host plants of the New York aster-yellows virus. Three of these, indicated by an asterisk in the list on page 574, are also hosts of the California aster-yellows virus.

\section{SUMMARY}

The host range of aster yellows among economic plants naturally infected includes 11 vegetables and 12 seed crops. These belong to 14 species in 12 genera in 6 families, including those previously reported (Severin, 1929a, $1932,1940)$. The virus overwinters in biennials, perennials, and overwintering leafhoppers.

The symptoms are described for each species or variety proved to be naturally infected. 
BAILEY, L. H.

\section{LITERATURE CITED}

1924. Manual for cultivated plants. 851 p. The Macmillan Company, New York, N. Y. DOolit'tLe, S. P., and F. L. Wellaman.

1934. Commelina nudiflora, a monocotyledonous host of a celery mosaic in Florida. Phytopathology 24:48-61.

DRAKe, C. F., H. D. TATE, and H. M. HARRIS.

1932. Preliminary experiments with aphides as vectors of yellow dwarf. Iowa State Col. Jour. Sci. 6:347-55.

1933. The relation of aphids to the transmission of yellow dwarf to onions. Jour. Econ. Ent. $26: 841-46$.

Frazier, Norman W., and H. H. P. Severin.

1945. Weed-host range of California aster yellows. Hilgardia 16(12:621-50.

KenKNight, G.

1943. The aster-yellows disease of vegetable and seed crops in Idaho. Idaho Agr. Exp. Sta. Leaflet 79:1-3. (Mimeo.)

KUNKEL, L. O.

1926. Studies on aster yellows. Amer. Jour. Bot. 13:646-705. Also in: Boyce Thompson Inst. Contrib. 1:181-240.

1931. Studies on aster yellows in some new host plants. Boyce Thompson Inst. Contrib. $3: 85-123$.

Severin, H. H. P.

1929a. Yellows disease on celery, lettuce, and other plants, transmitted by Cicadula sexnotata (Fall.). Hilgardia 3(18):543-83.

1929b. Curly top symptoms on the sugar beet. California Agr. Exp. Sta. Bul. 465:1-35.

1932. Transmission of carrot, parsley, and parsnip yellows by Cicadula divisa. Hilgardia $7(3): 163-79$.

1940. Potato naturally infected with California aster yellows. Phytopathology $30(12)$ : 1049-51.

1942. Infection of perennial delphiniums by California aster-yellows virus. Hilgardia $14(8): 411-40$.

Severin, H. H. P. and J. H. Freitag.

1945. Additional ornamental flowering plants naturally infected with California aster yellows. Hilgardia 16(12):599-618.

SMITH, R. E.

1902. Growing China aster. Hatch Exp. Sta. Massachusetts Agr. Col. Bul. 79:1-26. 


\section{PLATES}





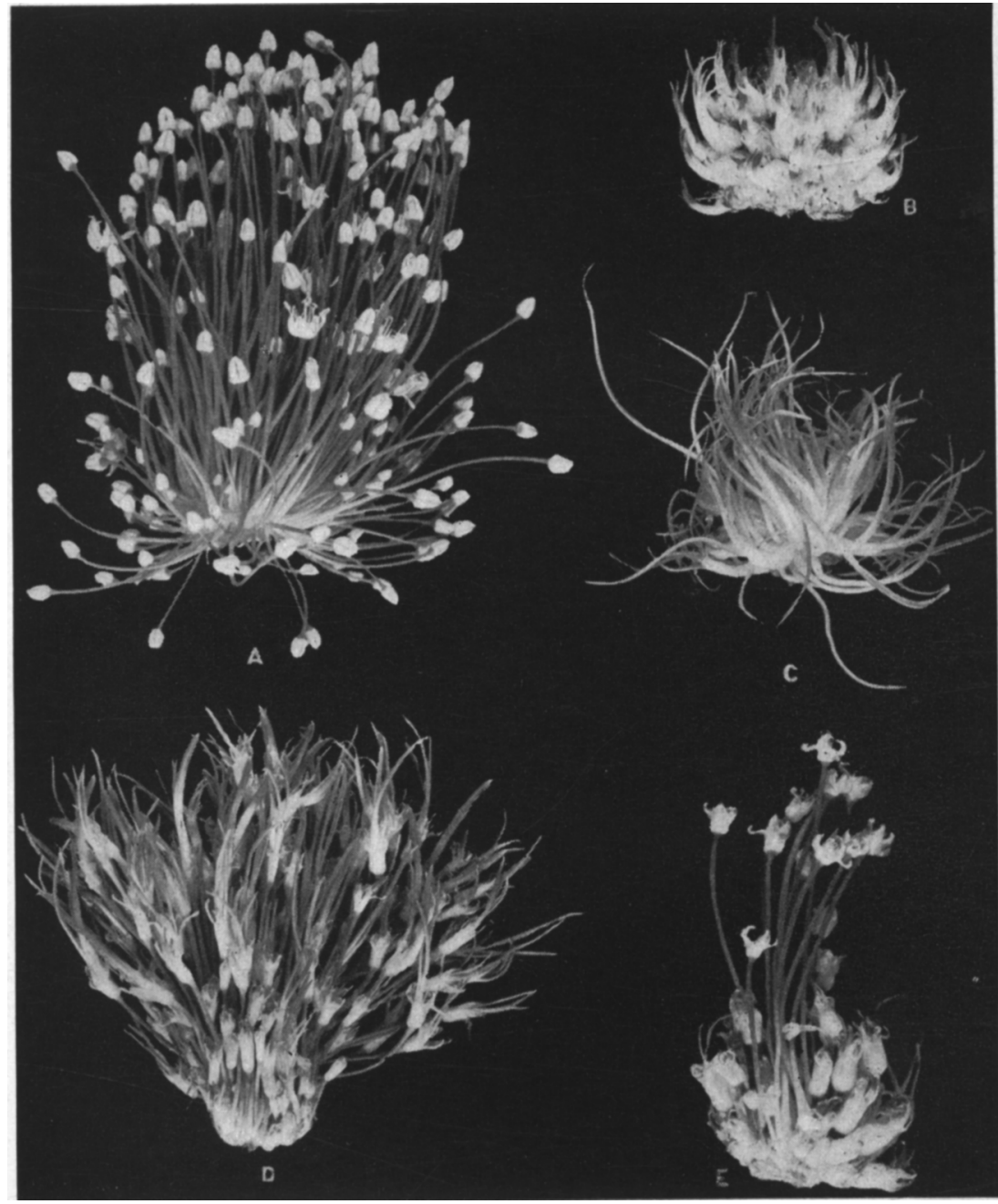

Plate 1-Onion naturally infected with aster-yellows virus: $A$, pedicels in terminal umbels, greatly elongated; $B$, sessile bulblets developed in the umbel instead of seeds; $C$, sessile onion bulblets that have developed yellow or green leaves; $D$, onion bulblets and flowers on pedicels; $E$, sessile onion bulblets and flowers on pedicels in same umbel. 


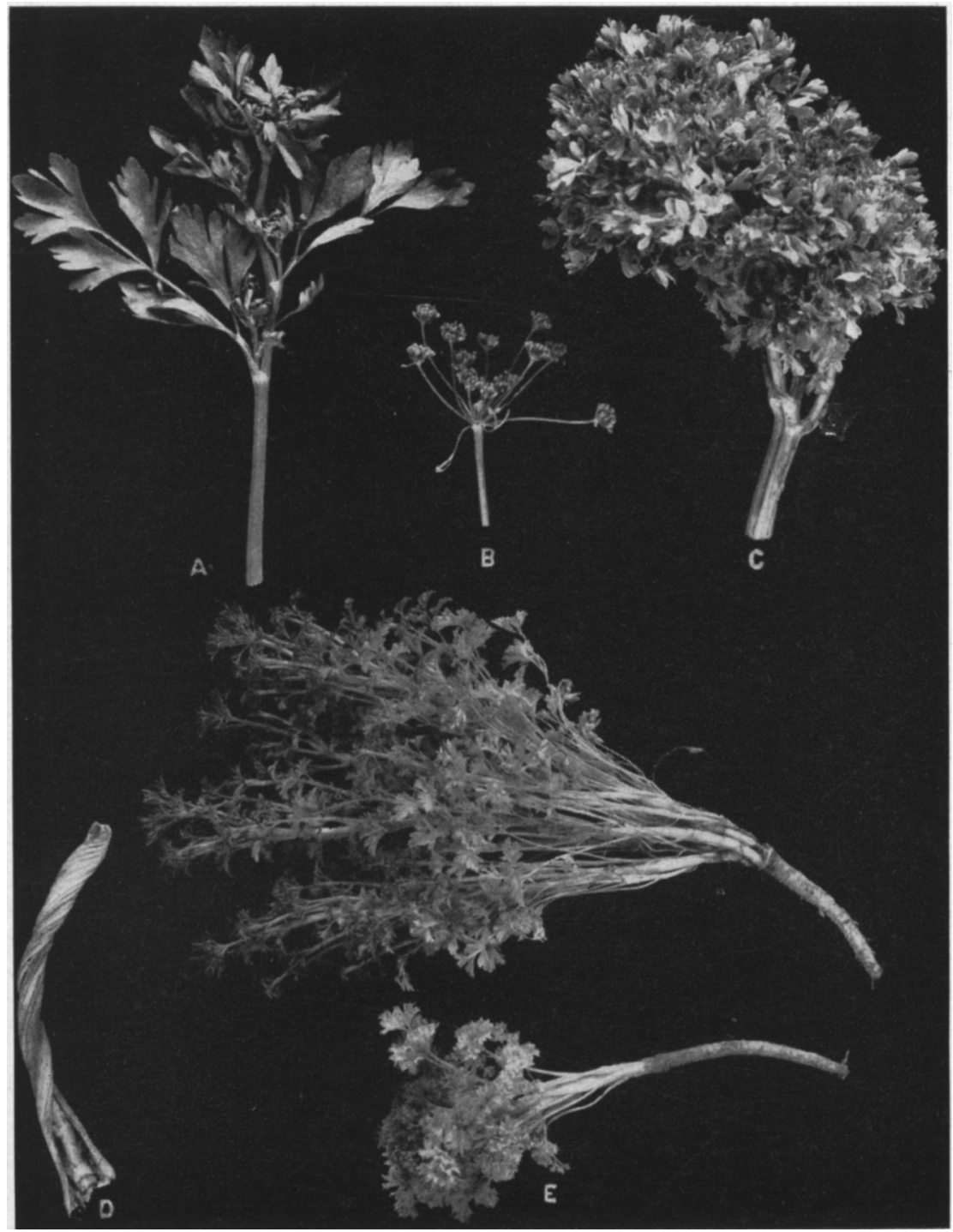

Plate 2.-A, B, Shoot and umbel from a healthy celery plant; $C$, cluster of shoots at the apical end of a branch from a celery plant, grown for seed, naturally infected with aster yellows; $D$, twisted petioles from parsley plants, grown for seed, naturally infected with aster yellows; $E$, parsley plants showing dense growth of adventitious shoots. 


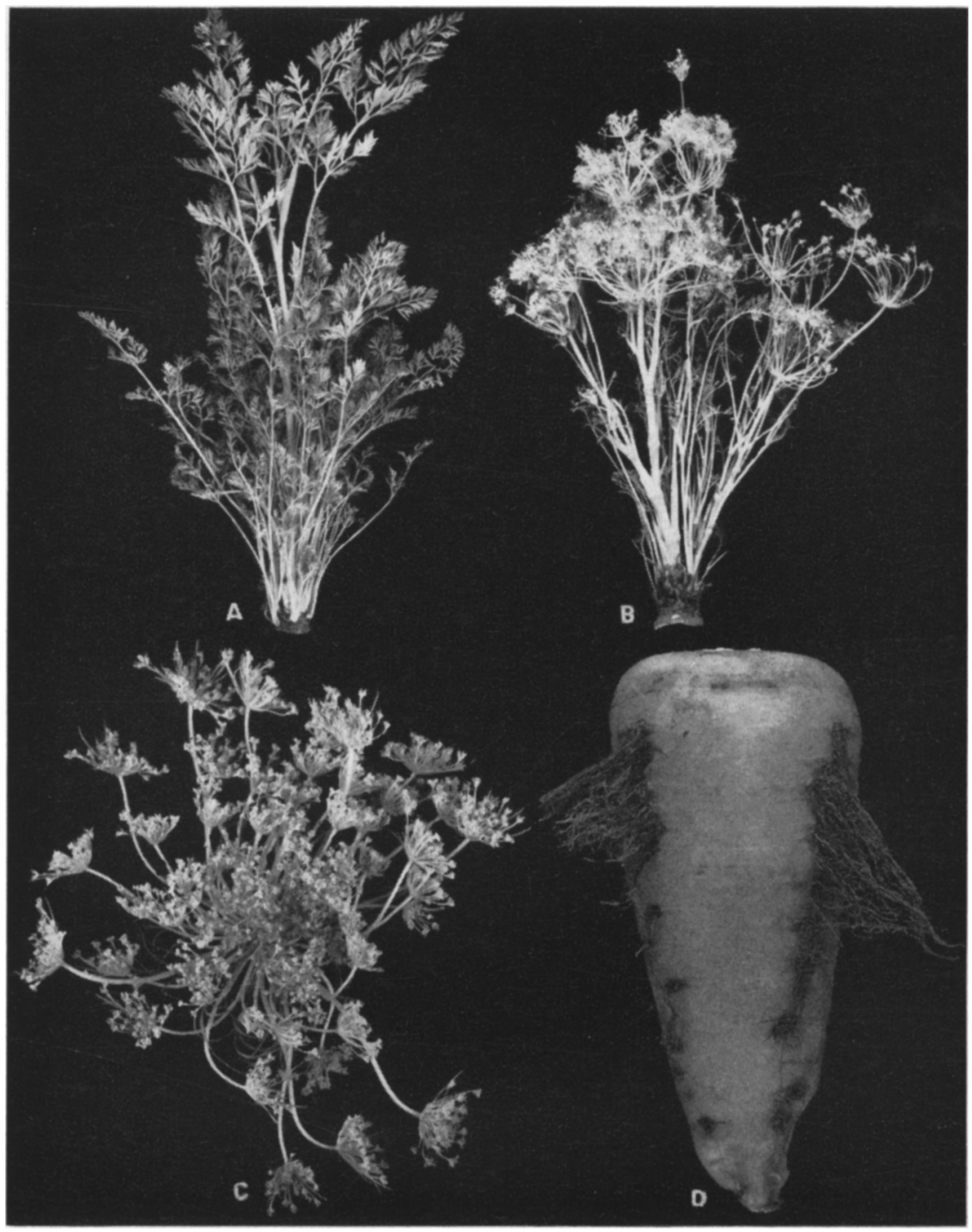

Plate 3.-Carrot plants, grown for seed, naturally infected with aster yellows; $A$, dense cluster of dwarfed, upright, adventitious shoots; $B$, numerous axillary shoots with dwarfed umbellets; $C$, umbellets showing elongated raylets and pedicels; $D$, carrot showing increase in number of rootlets. 


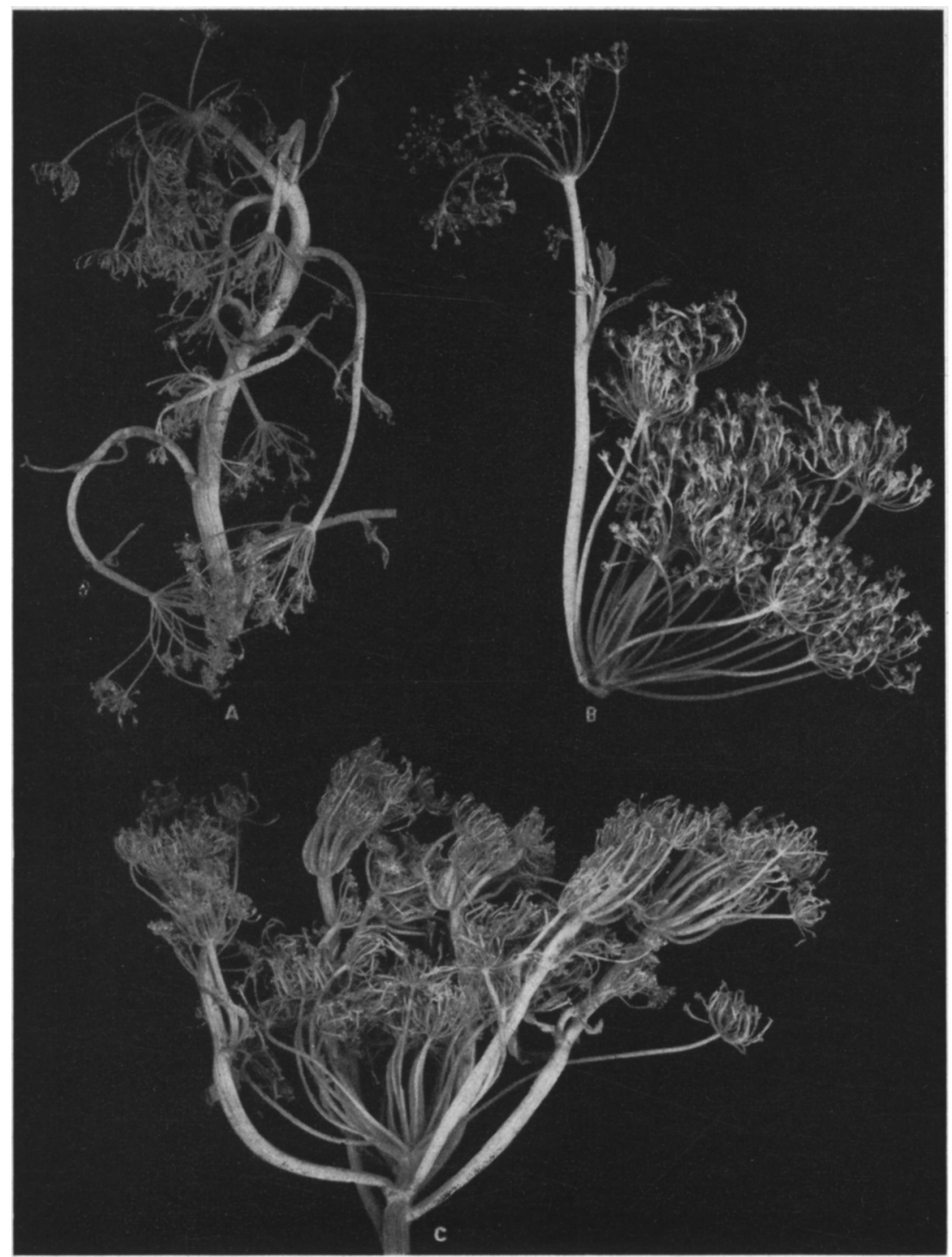

Plate 4.-Parsnip plants, grown for seed, naturally infected with aster yellows; $A$, curled and twisted stems; $B$, elongated raylets and pedicels; $C$, compound umbellets showing clusters of tangled raylets and pedicels. 


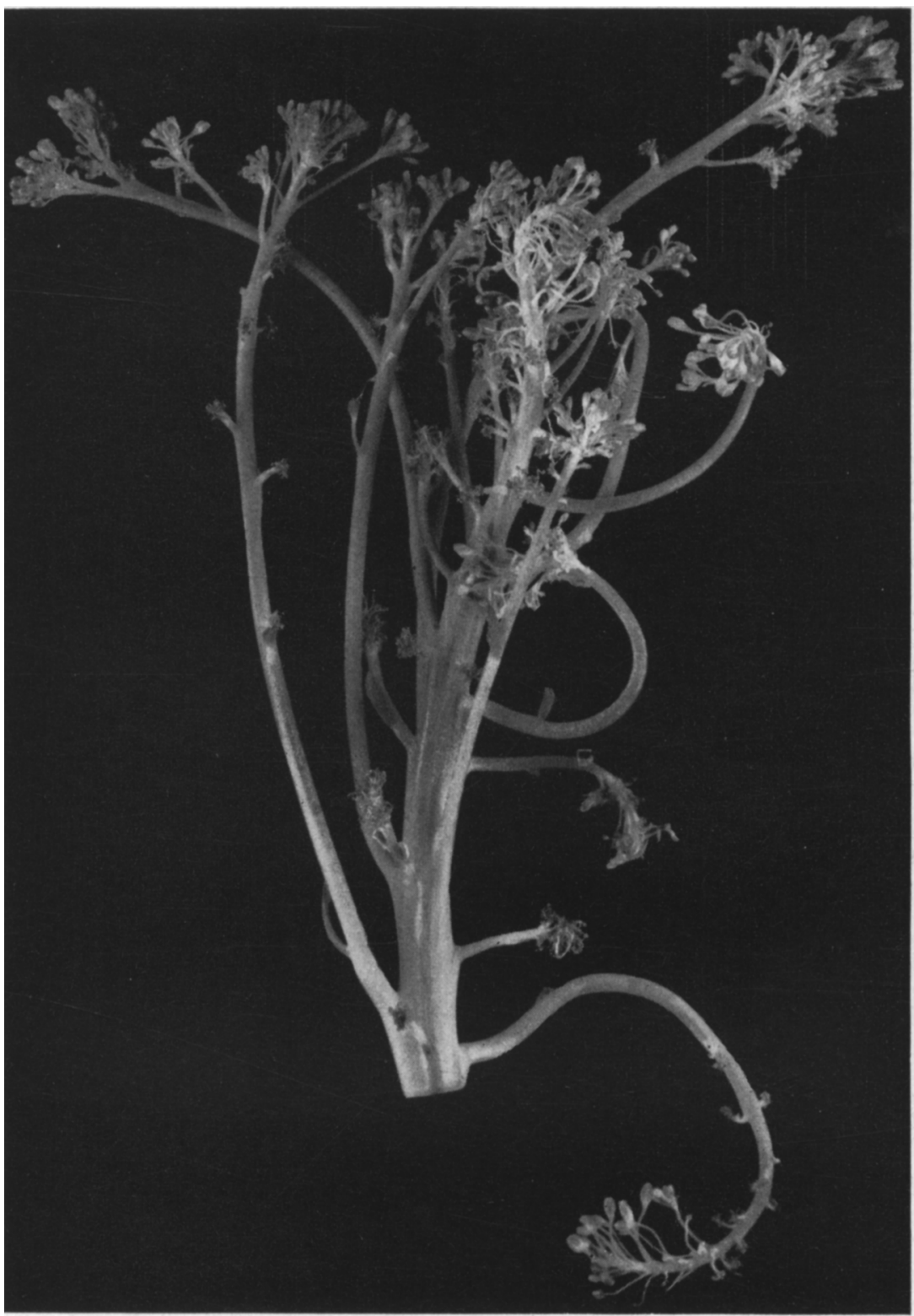

Plate 5.-Cauliflower plant, grown for seed, naturally infected with aster yellows, showing curved or twisted lateral flower stalks. 


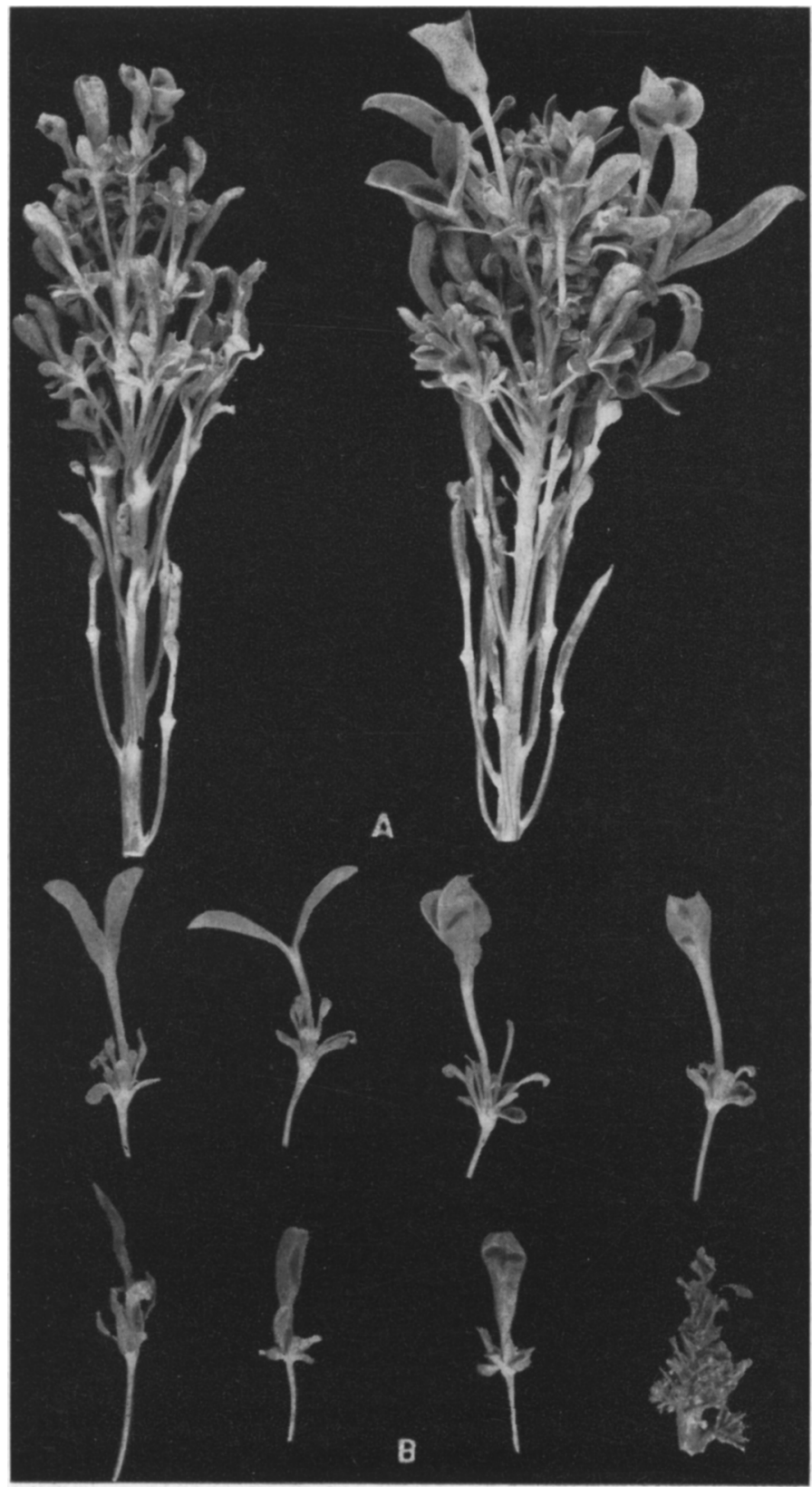

Plate 6.-Broccoli plants, grown for seed, naturally infected with aster yellows: $A$, profuse proliferation of the inflorescence, accompanied by phyllody, or the tendency of the floral organs to resemble leafy structures, and by virescence, or greening, of the flowers; $B$, enlarged leafy sepals, reduced petals, reduced or enlarged stamens, gynoecium elongated and frequently clubshaped, and carpels often bifurcate. Lower right, cluster of abnormal flowers. 


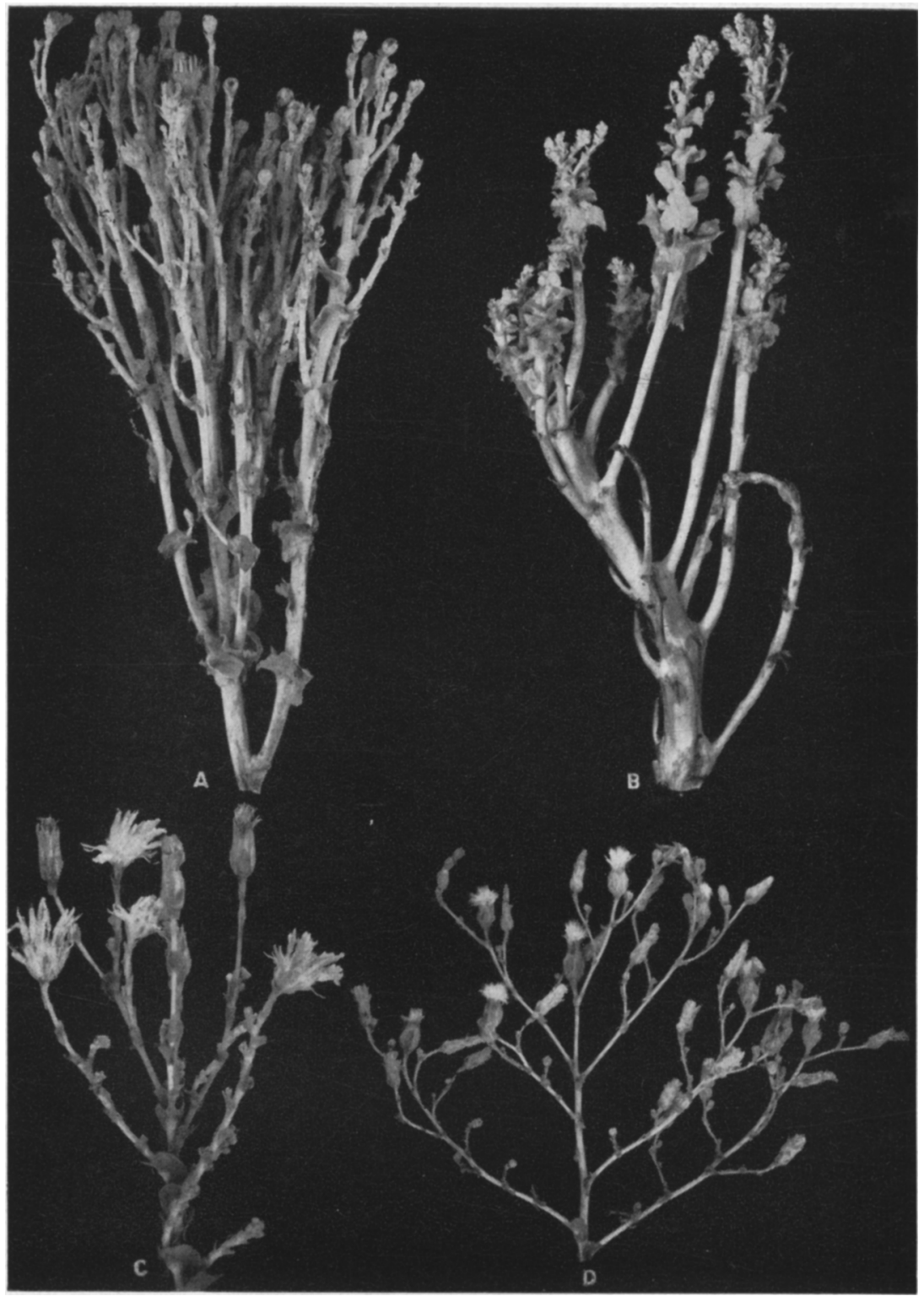

Plate 7.-Lettuce plants, grown for seed, naturally infected with aster yellows: $A$, upright or vertical branches, with secondary shoots rising from the axil of the leaves; $B$, curved or twisted branches; $C$, enlarged flower buds; $D$, normal flower buds and fruits with pappus of achenes protruding from a healthy plant. 

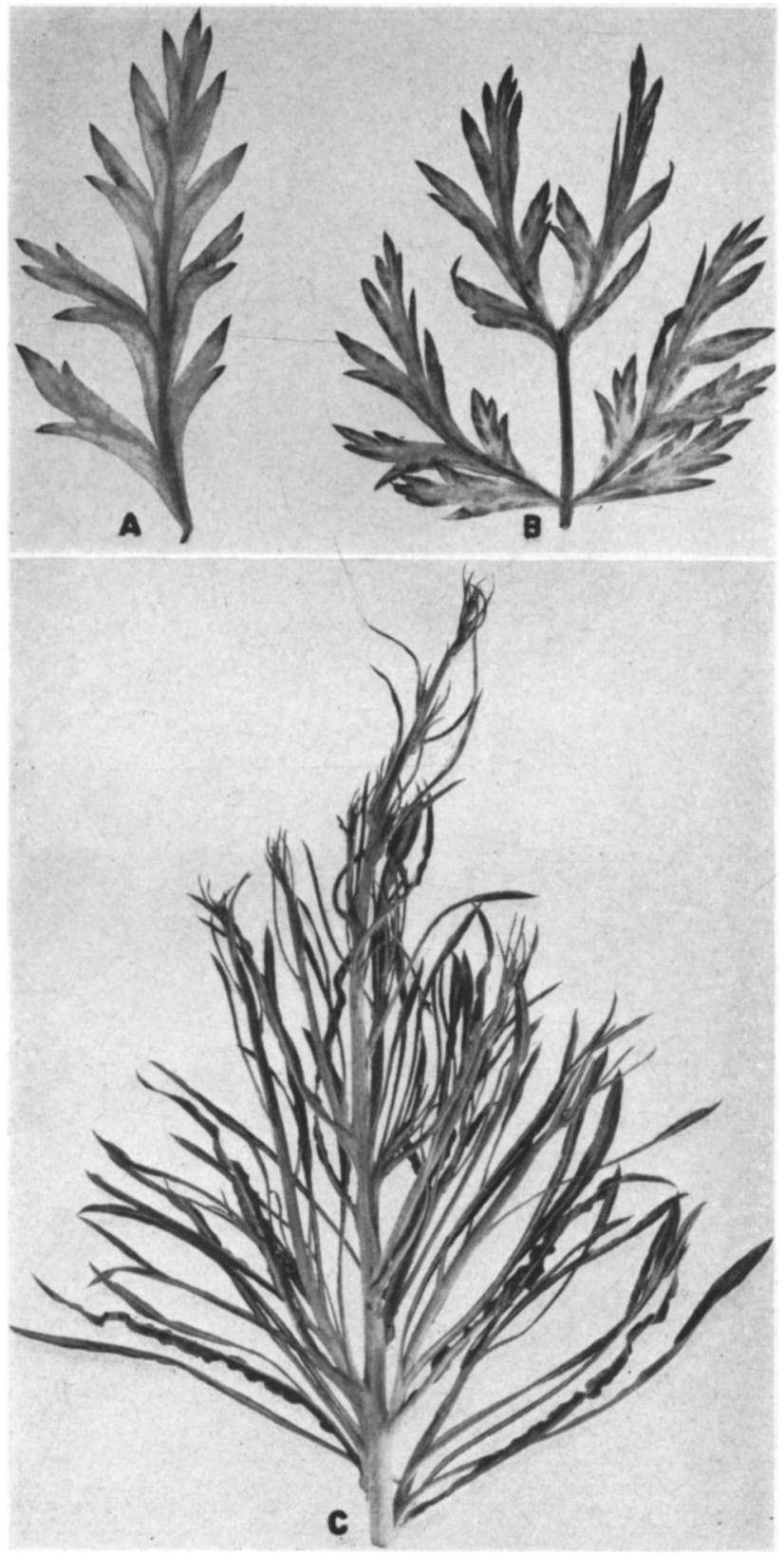

Plate 8.-Leaves from carrot plants, grown for seed, naturally infected with aster yellows: $A$, chlorotic leaf with green midrib and lat eral veins; $B$, margins of leaf purple instead of green; $C$, chicory plant, grown for seed, naturally infected with aster yellows, showing numerous axillary shoots, with the margin of the leaves undulating or wavy sometimes the leaf is twisted into a corkscrew. The flower buds are dwarfed, fail to expand, and are surrounded by linear leafy structures. 